\title{
UNUSUAL PRESENTATION OF MOLAR PREGNANCY - A CASE REPORT
}

Prameela $^{1}$, Syeda Mohsina Iffath ${ }^{2}$

\section{HOW TO CITE THIS ARTICLE:}

Prameela, Syeda Mohsina Iffath. "Unusual presentation of Molar Pregnancy - A Case Report". Journal of Evolution of Medical and Dental Sciences 2014; Vol. 3, Issue 08, February 24; Page: 2073-2075,

DOI: $10.14260 /$ jemds/2014/2105

INTRODUCTION: The Gestational trophoblastic diseases (GTD) are a group of pregnancy related disorders arising from abnormal placental trophoblastic cells comprising of partial and complete mole. Trophoblastic cells have malignant potential. Gestational trophoblastic neoplasia (GTN) is its malignant sequelae encompassing invasive mole, choriocarcinoma and placental-site-trophoblastic tumor.

KEYWORDS: Serum $\beta$ hCG, Ultrasonography, Methotrexate.

CASE REPORT: We report a case of 20year old gravida 2 with 1 spontaneous abortion 8 months ago with h/o 2 months amenorrhea presenting with complains of pain abdomen for 15 days. 0/E Uterus was 22 weeks size (doughy feel), P/V: cervix uneffaced, os closed. Clinical impression of molar pregnancy made, confirmed biochemically and sonologically. Her initial $\beta$ hCG values were 82, $100.6 \mathrm{~m} \mathrm{IU} / \mathrm{ml}$. She underwent suction evacuation during which she bled torrentially, and went into shock. Patient reviewed with dopamine drip.3PRBC's transfused.

Post evacuation her USG report showed mixed echogenic lesion with myometrial invasion. However her $\beta$ hCG values began to fall drastically. Subsequent scans showed heterogenous mass in the post. myometrium with no evidence of retained products. Oncologist's opinion taken and she was given single dose of methotrexate. Thereafter the USG reports showed a decreasing size of mass and vascularity. She was followed up serially till her $\beta$ hCG values were undetectable with a normal USG.

DISCUSSION: Varied heterogeneous presentations of molar pregnancies have been reported. 15$20 \%$ of complete moles can go for invasion characterized by trophoblastic proliferation invading the myometrium with edematous chorionic villi.

Invasive moles also have shown to have spontaneous regression. This case study would emphasize that high index of suspicion with chemoprophylaxis may be particularly useful in highrisk patients especially when loss to follow up is high. However $\beta$ hCG tires combined with TVS Doppler may be the best way to follow up patients with molar pregnancy.

CASE SUMMARY: We report a case of 20year old gravida 2 with 1 spontaneous abortion 8 months ago with h/o 2 months amenorrhea presenting with complains of pain abdomen for 15 days. 0/E Uterus was 22 weeks size (doughy feel), P/V: cervix uneffaced, os closed. Clinical impression of molar pregnancy made, confirmed biochemically and sonologically. Her initial $\beta$ hCG values were 82, $100.6 \mathrm{~m} \mathrm{IU} / \mathrm{ml}$. She underwent suction evacuation during which she bled torrentially, and went into shock. Uterine packing done, bleeding controlled. Patient reviewed with dopamine drip. 3PRBC's transfused. 
Post evacuation her USG report showed mixed echogenic lesion with myometrial invasion. However her $\beta$ hCG values began to fall drastically. HPR came as complete mole.

Subsequent scans showed heterogeneous mass in the post. myometrium with no evidence of retained products.

She was followed up weekly till her $\beta$ hCG values were undetectable, thereafter monthly for 6 months. Following which a repeat USG was done, that revealed a normal scan with no evidence of the mass.

Oncologist's opinion taken and she was given single dose of prophylactic methotrexate.

Thereafter the USG reports showed a decreasing size of mass and vascularity.

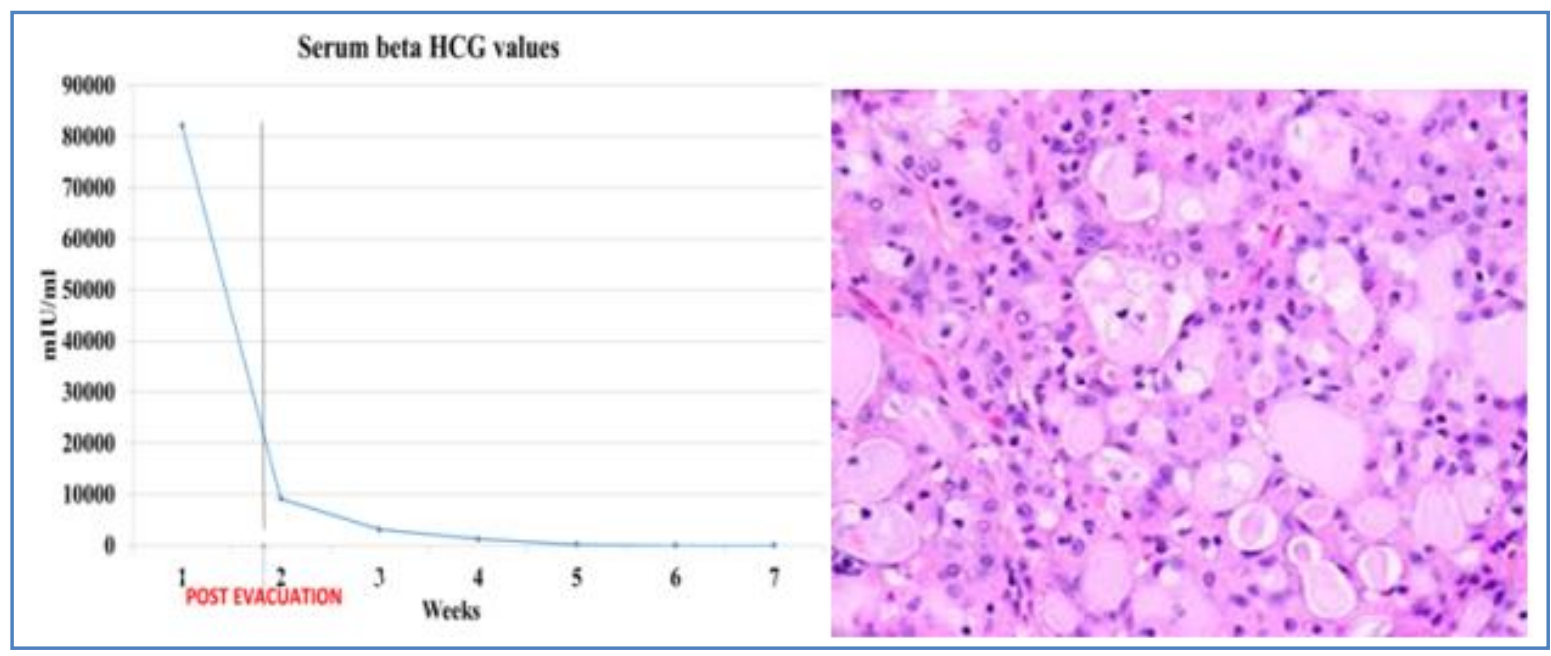

HISTOPATHOLOGY SHOWING COMPLETE MOLE

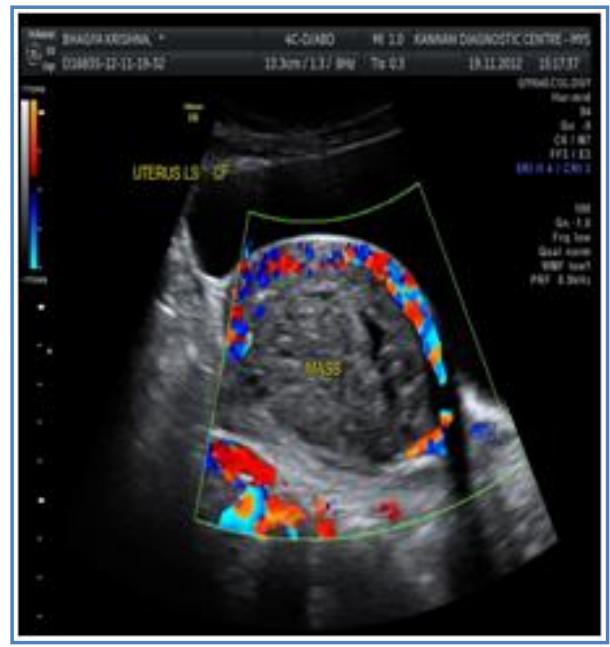

Post evacuation USG showing mass with increased myometrial vascularity

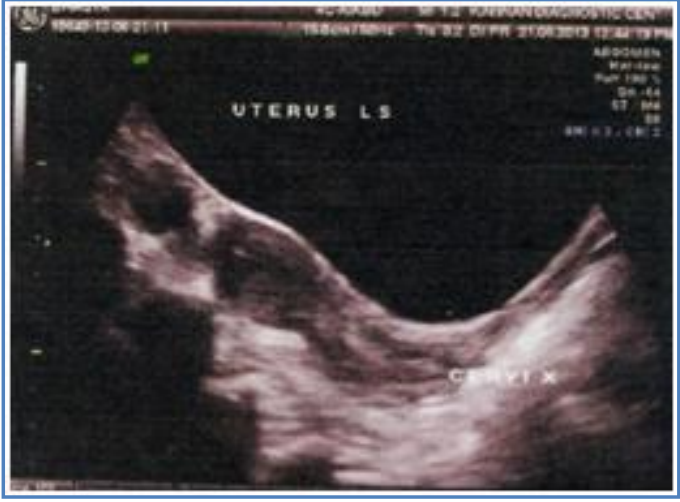

NORMAL USG AFTER 8 MONTHS FOLLOW UP 
DISCUSSION: Varied heterogeneous presentations of molar pregnancies have been reported ${ }^{1-5}$. 15$20 \%$ of complete moles can go for invasion 6 .Invasive moles (chorioadenoma destruens) are locally invasive, rarely metastatic lesions characterized microscopically by trophoblastic invasion of the myometrium with identifiable villous structures. Patients have persistent vaginal bleeding with elevated $\beta$ hCG titres post evacuation. Histopathology is the only confirmatory evidence of invasion. Invasive moles also have shown to have spontaneous regression?

CONCLUSION: In our case though we did not have elevated $\beta$ hCG titers, USG showed features suggestive of invasion. As well as the patient belonged to high risk group prophylactic chemotherapy was given. This case study would emphasize that high index of suspicion with chemoprophylaxis may be particularly useful in high-risk patients especially when loss to follow up is high. However BhCG tires combined with TVS Doppler may be the best way to follow up patients with molar pregnancy.

\section{REFERENCES:}

1. Suri V, Dhaliwal L, Gupta I, et al. An unusual presentation of gestational trophoblastic disease. Aust NZ J Obstet Gynaecol. 1999; 39:271-3.

2. Tehsim F, Arafat Y. Invasive mole as acute abdomen. Pak J Med Res. 2008; 47:48-9.

3. Pamela L, Mendelovici R. A case report of invasive mole with uterine rupture. J Gynecol Surg. 2009; 10:89-91.

4. Balagopal PG, Pandey M. Unusual presentation of choriocarcinoma. World J Surgoncol. 2003; 1:1477-8.

5. Vijay RKP, Kaduthodil MJ. Metastatic gestational trophoblastic tumour presenting as spontaneous subcapsular renal haematoma.Br J Radiol. 2008; 81:e234-7.

6. A Ilancheran. Optimal Treatment in Gestational Trophoblastic Disease. Ann Acad Med Singapore 1998; 27:698-704

7. Hertz R. Spontaneous regression in choriocarcinoma and related gestational trophoblastic neoplasms. Natl Cancer Inst Monogr. 1976 Nov; 44:59-60.

\section{AUTHORS:}

1. Prameela

2. Syeda Mohsina Iffath

\section{PARTICULARS OF CONTRIBUTORS:}

1. Associate Professor, Department of Obstetrics and Gynaecology, Mysore Medical College and Research Institute, Mysore.

2. Post Graduate, Department of Obstetrics and Gynaecology, Mysore Medical College and Research Institute, Mysore.

\section{NAME ADDRESS EMAIL ID OF THE} CORRESPONDING AUTHOR:

Dr. Prameela, No. $1391,1^{\text {st }}$ Cross, $3^{\text {rd }}$ Main, $2^{\text {nd }}$ Stage, Vijayanagar, Mysore - 560017. Email - hjprameela@gmail.com

Date of Submission: 30/11/2013. Date of Peer Review: 13/12/2013. Date of Acceptance: 30/12/2013. Date of Publishing: 24/02/2014. 